\title{
PEER OBSERVATION AS A TOOL FOR TEACHER'S PROFESSIONAL DEVELOPMENT AND THE WAY TO INCREASE THE QUALITY OF THE EDUCATION PROCESS
}

\author{
K.N. Volchenkova, volchenkovakn@susu.ru \\ South Ural State University, Chelyabinsk, Russian Federation
}

\begin{abstract}
Ever changing requirements to the academic staff in times of constant emergence of new learning tools and educational technologies put much pressure on the teachers and encourage them to find new and effective ways for continuous professional development in order to increase the quality of the learning outcomes and self-efficacy. Peer observation of teaching is one of the techniques that can improve professional skills if seen as a supportive and developmental tool. Evidence is emerging that the process of observing is just as if not more valuable than being observed and given feedback. The paper aims to define the term "peer observation". Based on the analysis of the literature different models of peer observation are described with the emphasis on the developmental model as the most fruitful one for continuous professional development. The benefits of peer observation to increase the quality of the educational process are given. The rationale to implement peer observation as part of a strategic approach to improve the quality of learning and teaching is provided. The findings can be used in the system of higher education to organize regular peer support for novice teachers and as part of continuous professional development programmes.

Keywords: peer observation, summative observation, formative observation, model, assessment, peer support.
\end{abstract}

The quality of education process depends on many factors. One of the factors is teacher's competence formed and improved during the professional life of a specialist. Peer observation of teaching is one method of evaluating teaching that can offer formative feedback to assist in the development of reflective processes of the teacher and to provide qualitative evidence to substantiate student evaluations [1]. The traditional view of the process also includes an assumption that colleagues can learn effectively from each other's explicit, constructive feedback about observed teaching. Peer observation is a technique used for various purposes in both learning and teaching. For the scope of the paper, we focus on peer observation for teachers as an instrument for continuous professional development and the source of learning.

Peer observation is not an innovative technology. It appeared in the USA in the 60 s and became a common technique. Administration of the universities used student-generated reviews of teaching staff that led to professional development programmes. Peer observation was an integral part of this process [2]. 20-30 years later, the practice was increasingly developed throughout the UK, but didn't become widespread in the 1990s [3]. While learning by observation in western universities is not exactly new, observation of teaching has only become a feature in Great Britain in the last decade. In Russian universities, peer observation is a technique that is used by the heads of the departments to decide on reappointment, tenure or redundancy. Though, the technique is developed thoroughly in Pedagogy until now it has been used exclusively for the evaluation of a teacher's competence. So, the potential of peer observation as a development tool has not been estimated and researched by Russian scholars.

Gosling [4] defines peer observation by deconstructing the individual terms in the title. A "peer" can mean a colleague from the same department, similar status, above or below your own grade, same age or experience. The nature of this relationship may change depending on why the observation is occurring. If peer observation is being used throughout a university it is vital that all staff members are regarded as genuine peers, and that there is real mutuality and respect for the participants, regardless of their status. The term "observation" incorporates the style of monitoring a teacher's work, the purpose and the form of observation. To make it objective it is suggested that some form of checklist is used. However, since most genuine peer observation is 


\section{Теория и методика профессионального образования}

developmental in nature, the checklist approach to data collection can be limiting and it is suggested that a more open, informal recording measure should also be incorporated. This ensures that the observer is not merely relying on memory and interpretation without any evidence, while at the same time not being limited to the strict format of a checklist. To make an observation more precise and objective a combination of techniques should be used. So, peer observation is a technique used for evaluation or developmental purposes, where colleagues observe each other's practice to provide feedback and discussion that will promote reflection and support professional development.

The principle types of peer observation are formative and summative ones. Formative evaluation typically is oriented solely towards the improvement of teaching and is part of instructional mentorship and development. Summative evaluation, in contrast, is that done to inform personnel decisions. To improve the freedom and exploration of individual faculty, formative reviews may be shielded from scrutiny for a period of years until such time that there needs to be accountability to standards of excellence for personnel decisions. At this point in time, summative evaluations are more common since they are tied to decisions related to reappointment, promotion, or tenure $[5,15]$. Because the more consequential nature of summative evaluations tends to diminish the formative value of the peer review process, it is important to maintain a clear distinction between these types of evaluation and be transparent with those under review. It is also common to have different faculty involved in each form of assessment - mentor faculty in the formative evaluation and departmental or program administrators, such as chairs, involved in summative evaluations.

Summative evaluation rarely provides sufficient information to teachers for improving teaching. In recent years, in fact, time-honored practices of faculty evaluation have been rather harshly criticized. In response to this, scholars have recommended that assessment specifically designed to improve teaching should be put into place alongside, but apart from, summative evaluation. Other scholars have suggested that formative peer-assessment, a process in which work collaboratively to assess each others' teaching and to assist one another in efforts to strengthen teaching, be developed and implemented. Collaborative peer observation probably should in- clude opportunities to teachers to learn how to teach more effectively, to practice new teaching techniques and approaches, to get regular feedback on their classroom performance, and to receive coaching from colleagues [6].

Academics might like peer-observation if they are sure that it is confidential, if they have a curiosity about their colleagues' teaching methods and strategies, an interest in improving their own teaching effectiveness, or feel comfortable being observed in the classroom because they have previously experienced observations [7]. Conversely, academic staff might resist being observed if they have concerns about the objectivity of the observer or the accuracy of what is reviewed, or if they feel that the observation might restrict their academic freedom [8].

In a survey conducted among the teachers of foreign languages department (South Ural State University) with 28 teachers participating in a survey, only half of the teachers wanted to take part in the peer observation process. $40 \%$ of the teachers admitted that the experience of being observed was both positive and negative for them. $90 \%$ agreed that peer observation is an effective tool for professional development. $85 \%$ agreed that they need a training session to observe efficiently and that giving feedback is a special skill to be learnt. $15 \%$ of the teachers admitted that peer-observation causes more stress than benefits. Time constraints, busy workloads, and fear of scrutiny and criticism were identified as issues that might inhibit participation in the process. With all these having in mind we can conclude that peer observation is a technique to be learnt being sensitive by nature and elaborate in terms of giving feedback with the primary focus on support and not judgment.

There are several models of peer observation (Table 1). These models differ on the basis of either the number of observers (i.e. pairs, trios, or larger groups) or the purpose of the observation: an evaluation model; a developmental model; and a peer-review model [5]. In the evaluation model, it is usually a senior faculty member who observes others, while in the developmental model, the observer is an educational developers, expert or teaching practitioner. The essence of the peerreview model however, is that teachers observe each other, often in a reciprocal process. They are not being judged by any externally set criteria; instead, the assessment is based around a set of mutually agreed issues [9]. One could even argue that the evaluation and developmental models are 
not actually peer models, because of existing power relationships in the earlier two models.

Table 1

\section{Models of peer observation}

\begin{tabular}{|l|l|}
\hline \multicolumn{1}{|c|}{ Model } & \multicolumn{1}{c|}{ Objective } \\
\hline $\begin{array}{l}\text { Evaluation } \\
\text { model }\end{array}$ & $\begin{array}{l}\text { Identify under-performance, } \\
\text { confirm probation, appraisal, } \\
\text { promotion, quality assurance, } \\
\text { assessment }\end{array}$ \\
\hline $\begin{array}{l}\text { Developmental } \\
\text { model }\end{array}$ & $\begin{array}{l}\text { Demonstrate competency, } \\
\text { improve teaching competen- } \\
\text { cies; assessment quality en- } \\
\text { hancement and professional } \\
\text { development }\end{array}$ \\
\hline $\begin{array}{l}\text { Peer-review } \\
\text { model }\end{array}$ & $\begin{array}{l}\text { Engagement in discussion } \\
\text { about teaching; self and mu- } \\
\text { tual reflection on good prac- } \\
\text { tice among academic staff }\end{array}$ \\
\hline
\end{tabular}

The developmental model assumes that we have a strong evidential basis for knowing what good practice in teaching is. There is evidence that advice given to teachers does lead to them adopting a more student-centered approach in their teaching.

The efficacy of formative and summative evaluations of faculty teaching is investigated by Cavanagh [10]. He stresses the fact that both types of review should be subjected to rules, criteria, and standards, so as to identify the effectiveness of teaching. These criteria are decided via peer conversation among members of a scholarly unit. The intrinsic aim for the criteria agreed upon is, he thinks, to clarify the expectations for curriculum design, teaching methodologies, and the potential learning outcome.

Whether it is conducted for formative or summative purposes, peer observation comprises a simple, three-stage process:

1. A pre-observation meeting where the participants discuss the process. This preliminary meeting allows the observer to gain an understanding of the session to be observed.

2. The observation or actual classroom visit.

3. A post-observation meeting where there is debriefing, plus reflection by both parties on what has taken place.

Where peer-observation is summative and forms part of a formal program, further administrative steps are involved: before the pre-observation meeting (notification of the upcoming observation to both participants) and after the post-observation meeting (production of a written report, and dissemination of findings to the department or program, perhaps with a view to identifying staff development needs).

Topics discussed at the pre-observation meeting should include: the lesson plan for the session; the key learning objectives; the teaching approaches or methods to be adopted; and the context of the teaching (room, timetable, the status and history of the student group). Participants would also negotiate the role of the observer in the session; how the students will be informed of the upcoming visit; and aspects of teaching that the observee would like to receive feedback upon [5]. In cases where it is not possible to meet up before the observation, contact by email or phone may replace the pre-observation meeting [5].

During the classroom visit, it is important to keep the behaviour of participants as natural as possible to ensure that what the observer witnesses is representative of the instructor's teaching practice. For this reason, Gosling [5] recommends that the observer sit where they are not in the overt line of vision for the instructor or the group, but where they can see both instructor and group. In the ideal case, the postobservation feedback meeting takes place as soon as possible after the observation meeting. Ideally, no more than a week should elapse between the meetings [5].

Observer and observee share a joint responsibility to keep the feedback focused and constructive $[5,11]$. A good feedback session will allow the instructor the opportunity to selfdiagnose any possible weaknesses in their own teaching performance. Wherever possible, assessors should strive to be supportive and positive in their feedback and comments. To this end, Bell [11] recommends the use of open-ended questions.

Peer observation becomes especially valuable when new techniques are introduced into the education process. The adoption of a new technology is time-consuming and many hurdles teachers face can be settled through peer support. In the context of the continuous development scheme, the definition of peer observation of teaching is the formal process by which the good practice of staff engaged in learning and teaching activities is identified, disseminated and developed. Peer observation can also be seen as a reflective tool for a teacher.

The concept of reflective practice and its potential role in professional, personal and organizational development in higher education is fun- 


\section{Теория и методика профессионального образования}

damental to the scheme. Askew [12] reports that a reflective model of peer observation of teaching can become a key process in the professional learning of academic staff/faculty and contribute to fashioning a consciously reflective learning organization. Indeed, it can prevent teachers from becoming isolated and teaching from becoming routine and mundane. Linked to this, the current scheme utilizes a mentoring component; mentoring literally means 'wise and trusted advisor or counselor. It is an essential aid to the academics' professional development, looking beyond dayto-day activities to the future through fostering talent and potential.

Scholars have suggested that a number of personal and institutional benefits might be realized from teachers participation in the formative peer evaluation of teaching. These include improvement teaching, teachers' morale, collegiality and student learning. Peer observations are particularly useful for self-assessment and improvement of teaching skills; but it is important for participants to keep in mind that what is gained through peer observation will ultimately benefit students. Therefore, observation is intended for reviewing the teaching process and it is relationship to student learning. Peer observation is an exercise, which can promote collegiality and a learning environment and atmosphere as well as bring affective benefits to the observer and the teacher. In many departments, there is often an attitude that teaching is a secretive activity, which takes place behind closed doors; the prevailing discourse is often one of wonder and curiosity about others' teaching. Peer observation provides an opportunity to open up the doors and reveal what is taking place on an everyday basis. Regardless of what teachers observe, this is in itself a reassuring activity. Eddy and Garza Mitchell [13] specifically refer to the importance of faculty sharing to diminish the notion that teaching is a solo activity and to motivate experienced faculty to be more engaged in the learning process.

Opening up the classroom through peer observation also gave confidence to some teachers. This confidence stemmed from confirmation that what they were doing was acceptable.

Ultimately, peer observation aims to provide the participant with feedback, support and assistance from their colleagues. Moreover, when they observe, they will be able to see teaching from the students' perspective. Webb [15] believes the more we as teachers can share a common form of life and common experience with others in our institutions, the greater is the possibility that we will be able to extend our horizons to encompass a fuller understanding of our strengths and weaknesses.

\section{References}

1. Hammersley-Fletcher L., Orsmond P. Evaluating our Peers: is Peer Observation a Meaningful Process? Studies in Higher Education, no. 29:4, pp. 489-503. DOI: 10.1080/0307507042000236380

2. D'Andrea V. Peer Review of Teaching in the USA. Available at: www.heacademy.ac.uk/ resources (accessed 17.05.2016).

3. Shortland S. Peer Observation: a Tool for Staff Development or Compliance? Journal of Further and Higher Education, 2004, no. 28(2), pp. 219-228. DOI: $10.1080 / 0309877042000206778$

4. Gosling D. Peer Observation of Teaching. SEDA, 2005, p. 118.

5. Bernstein Daniel J., Jonson J., Smith K. An Examination of the Implementation of Peer Review of Teaching. New Directions for Teaching and Learning, 2000, no. 83, pp. 73-86. DOI: $10.1002 / \mathrm{tl} .8306$

6. Menges R.J. Career-Span Faculty Evaluation. In College Teaching, 1985, vol. 33, pp. 181184. DOI: $10.1080 / 87567555.1985 .10532317$

7. Keig L. Formative Peer Review of Teaching: Attitudes of Faculty at Liberal Arts Colleges toward Colleague Assessment. Journal of Personnel Evaluation in Education, 2000, no. 14 (1), pp. 67-87.

8. Keig L., Waggoner M. Peer Review of Teaching: Improving College Instruction through Formative Assessment. Journal on Excellence in College Teaching, 1995, no. 6 (5), pp. 51-84.

9. Ewens D., Orr S. Tensions between Evaluation and Peer Review Models: Lessons from the $H E / F E$ Border. Available at: www. heacademy.ac.uk (accessed 25.05.2016).

10. Cavanagh R.R. Formative and Summative Evaluation in the Faculty Peer Review of Teaching. In Innovative Higher Education, 1996, vol. 20, no. 4, pp. 235-240. DOI: 10.1007/BF01185798

11. Bell M. Peer Observation Partnerships in Higher Education. New South Wales, Milperra Publ., 2005.

12. Askew S. Learning about Teaching through Reflective, Collaborative Inquiry and Observation. Learning Matters, 2004, no. 15, pp. 2-4. 
13. Eddy P.L., Garza Mitchell R.L. Faculty as Learners: Developing Thinking Communities. Innovative Higher Education, 2012, no. 37(4), pp. 283-296. DOI: http://dx.doi.org/10.1007/s10755-011-9202-z

14. Webb G. Understanding Staff Deve- lopment. Buckingham, The Society for Research into Higher Education \& The Open University Press Publ., 1996.

15. Goody A. Peer Observation of Teaching. Presented at the Foundations of Teaching and Learning Program. 2005.

Received 1 June 2016

УДК 378.016

DOI: $10.14529 /$ ped160304

ББК Ч448.44

\title{
ВЗАИМОПОСЕЩЕНИЕ ЗАНЯТИЙ КАК ИНСТРУМЕНТ ПРОФЕССИОНАЛЬНОГО РАЗВИТИЯ ПРЕПОДАВАТЕЛЯ И СПОСОБ ПОВЫШЕНИЯ КАЧЕСТВА ОБРАЗОВАТЕЛЬНОГО ПРОЦЕССА
}

\author{
К.Н. Волченкова \\ Южно-Уральский государственный университет, г. Челябинск
}

\begin{abstract}
Растущие требования к профессорско-преподавательскому составу и уровню компетентности, связанные с появлением новых технологий обучения, приводят к необходимости внедрения дополнительных форм профессионального развития, поиска эффективных способов повышения качества образовательного процесса. Взаимопосещение занятий один из методов, который может способствовать повышению уровня профессиональных умений, если использовать его в качестве инструмента поддержки и развития профессорско-преподавательского состава.

Целью статьи является критический анализ значения и содержания термина «взаимопосещение занятий». Приводится классификация различных моделей взаимопосещения занятий, их типы, этапы процесса взаимопосещения занятий. Описываются преимущества использования модели взаимопосещения занятий для преподавателей вузов. Дается обоснование внедрению модели взаимопосещения занятий в качестве инструмента повышения качества обучения. Результаты исследования можно использовать в системе высшего образования для организации курсов повышения квалификации и содействия профессиональному росту преподавателей.
\end{abstract}

Ключевые слова: взаимопосещение занятий, взаимооиенка, модель, взаимоподдержка.

Волченкова Ксения Николаевна, кандидат педагогических наук, зав. кафедрой иностранных языков, Южно-Уральский государственный университет, Челябинск, volchenkovakn@susu.ru

Поступила в редакцию 1 июня 2016 2.

\section{ОБРАЗЕЦ ЦИТИРОВАНИЯ}

Volchenkova, K.N. Peer observation as a tool for teacher's professional development and the way to increase the quality of the education process / K.N. Volchenkova // Вестник ЮУрГУ. Серия «Образование. Педагогические науки». - 2016. - Т. 8, № 3. - С. 39-43. DOI: $10.14529 /$ ped 160304

\section{FOR CITATION}

Volchenkova K.N. Peer Observation as a Tool for Teacher's Professional Development and the Way to Increase the Quality of the Education Process. Bulletin of the South Ural State University. Ser. Education. Educational Sciences. 2016, vol. 8, no. 3, pp.39-43. DOI: $10.14529 /$ ped160304 